\title{
Time and Cost Performance of Fixed Price Building Contracts in Tertiary Institutions in Nigeria
}

\author{
Joshua S. M angvwat ${ }^{1 *}$, Duga J. Ewuga', Yohanna D. Izam² \\ ${ }^{1}$ D epartment of Q uantity Surveying, University of J os-Nigeria \\ ${ }^{2}$ Department of B uilding, U niversity of J os-Nigeria
}

\begin{abstract}
This qualitative and quantitative study evaluates the time and cost performance of fixed-price contracts in Tertiary Institutions projects in Plateau State, funded as intervention projects from the Tertiary Education Trust $F$ und. Literature review gives the background on the types and forms of contracts. Questionnaires, interviews and records from projects are tools that were used in collecting the relevant data. Sixty-two professionals consisting of 12 A rchitects, 8 B uilders, 12 Engineers, 22 Quantity Surveyors and 8 Estate Surveyors randomly selected responded to issues of time and cost challenges. Records were purposively obtained from Twenty-Three projects studied. Regression A nalysis was used to predict the time and cost performance. Results show a cost increase of $\$ 14,423.59$ for every onemonth increase in time. Interviews revealed all 23 projects suffered time overruns with only 5 overrunning in cost. Specifications of 18 projects were found to be changed in order to satisfy the client's budget objective of the firm price. The research recommends that to enhance time and cost performance, designs must be fully completed before biding. A Iternatively, the entire procurement system which favours the fixed price arrangement should be overhauled to accommodate other options.
\end{abstract}

Keywords: Fixed Price, Time, Cost, Performance, Building Contract

\section{Introduction}

Due to the complexity of construction projects and the high demand from construction clients, various forms of building contracts are employed by the parties involved to deliver the project successfully [1]. Bennett [2] explained that the procurement method and type of project determine the choice of the contract to be used. Procurement of construction projects is the network of relationships amongst the various parties involved in the delivery of a project. This relationship is formalised by entering into a legal contract [1]. The contracts, therefore, have to be tailored towards the construction client's needs and objectives. The latter revolves around the triumvirate of

- $\quad$ Cost (initial expected cost, capital cost and maintenance cost), 
- Time (time required for design and construction, securing timely planning approvals, timely completion etc.) and

Quality (expected in terms of design flexibility to changes, technical specification, functionality and aesthetics/workmanship) [1, 3, 4].

Other factors that determine the type of procurement method and contracts to be used are the size, type and complexity of the project because the performance of a construction project is related to the method of procurement used in its delivery [5]. Also, the level of participation of the client mostly influences the success or failure of a project $[4,6,7]$. The client's influence can be exerted through deciding the type of contract strategy to be used which guides the decision on the form of payment. These contract strategies can be either pricedbased or cost-based. The priced-based are lump-sum or re-measurement contracts with prices being submitted by the contractor in their bid while the cost-based are cost-reimbursable or target cost where the actual cost incurred by the contractor is reimbursed with a fee added to cover for overheads and profit [8]. Potts [8] further explained that the allocation of risks to the parties involved in the contract is also a factor that determines the choice of the payment system.

The procurement of public projects in Nigeria is conducted mainly through the traditional procurement system, using mostly price-based contract strategy. Olatunji [9] observes that public projects in Nigeria awarded based on the lowest price has led to contractors bidding with ridiculous rates while delivering very low-quality work and workmanship. He further observed that from the projects studied, only $44 \%$ were completed within budget and only about $5 \%$ these were delivered within the actual completion time [9]. Also, Adedokun et al. [10] reveal that educational projects in Nigeria are mostly procured through the open competitive tendering method. They explained that using this method of tendering is influenced by the need for obtaining high quality, accountability, price competition, and speedy execution. However, Olanrewaju and Anavhe [11] observe that construction projects in Nigeria have suffered from a lot of claims; some of the major sources of the claims include late payment, delayed approval of change order and delay cost which was noted to be extremely influential while the least influential were storage charges, loss of productivity, and costs of preparing claims. They found that major claim factors are behavioural rather than technical issues [11].

With the amount of investment made on infrastructure projects in Nigeria, especially in higher educational institutions through the Tertiary Education Trust Fund (TETFUND) funding there is the need for a better understanding of the performance of these projects in meeting the client's objectives. In addition, it is necessary to understand how the price based (lump-sum/fixed contract) system of the contract has helped in meeting the client's needs and objectives and also to identify areas of necessary improvement to ensure that such projects meet the client's objectives.

\section{Literature Review}

Background of TETFUND and procurement/contract strategies in use in construction is reviewed.

\subsection{Background on Tetfund}

The Tertiary Education Trust Fund (TETFUND) was set up to administer and disburse education tax collections to Federal and State tertiary educational institutions in Nigeria. The main source of income available to the Fund is the $2 \%$ education tax paid from the assessable profit of companies registered in Nigeria. The Board of Trustees (BOT) of the Fund is statutorily charged with the responsibility of administering, managing and disbursements 
of these funds to beneficiaries in the public tertiary educational institutions under established guidelines. The Act that set up the fund prescribes the distribution of the funds in the ratio 2:1:1 respectively to Universities, Polytechnics and Colleges of Education (COE). TETFUND has been responsible for over $60 \%$ of the infrastructure development in public tertiary institutions in Nigeria. This translates to One Trillion Naira expenditure (about \$2.78 Billion) within a period of five years. Based on the 2016 allocation alone, 181 tertiary institutions comprising 74 universities, 50 polytechnics and 57 colleges of education benefitted from the particular fund $[12,13]$.

\subsection{Procurement systems and Construction Contracts}

Procurement of construction projects is the outcome of a chain of relationships amongst the various parties involved in the delivery of a project [1]. Different procurement methods use different types of contract. For example, The Joint Contract Tribunal (JCT) [14] identified the fixed-price contract as one of three types of the contract under the traditional procurement methods. It describes a fixed price contract as an arrangement where the contract sum is determined before the beginning of construction work. The contractor undertakes a defined task in return for an agreed amount of money. Furthermore, Rodriguez [15] opined that in a fixed price contract, the owner has essentially assigned all the risk to the contractor, who in turn charges a higher percentage of the cost as a safety net should any unforeseen circumstance arise.

In theory, the different contractual arrangements have a different effect on the time, cost, and quality as well as in the allocation of the risks among parties involved. These are the most important parameters, which are critical to building project performance [16]. According to the Construction Industry Institute, the main difference with respect to a fixedprice contract is the risk factor. This is because risk has a significant impact on construction project performance. How risks are shared between the parties is to a large extent governed by the procurement option and the content of the related contract document and forms [17].

In comparing the tender sums and final costs of construction projects in Nigeria awarded using due process procedures from 2003 - 2007, Olatunji [9] found that all the projects awarded were based on the lowest price. He observed that apart from the fact that it weakens competition, as some contractors are still found bidding with very ridiculous rates, low quality of workmanship and project's poor performance in its entire life are probable features of many of these projects. He further found that although 44 per cent of the construction projects were completed within budget, only 5 per cent were delivered within time. Also, Shwarka and Anigbogu [18] in examining the impact of public procurement options on building projects performance in Nigeria based on the impact of traditional and design and build methods found that there is no significant difference between the two in terms of quality but that there is a significant difference in duration and cost.

\section{Methodology}

This research adopted the strategy of a case study in a survey [19]. Data is collected using a combination of library/desk search, questionnaire and personal interviews. Project files are examined and interview questions are developed to enable this. A list of time, cost and variation variables were drawn from literature and from discussion with the parties involved in the projects. An interview guide was prepared based on the compiled list after a pilot study. The piloting improved the wording and increase the reliability of the questions asked. These were structured into the questionnaire we have used. Respondents were required to rate the frequency and severity of each of the factors using a 5 - point Likert scale. The primary data 
was collected from the contract documents, progress reports, and minutes of monthly site meetings, correspondences as well as available site records.

The research focused on TETFund sponsored projects in tertiary institutions in Plateau state. The target population consists of three groups, namely contractors, consultants'/client's representative and construction professionals because of their expertise and experience in the projects studied.

Data collected are presented and analysed using descriptive statistics and Regression Analysis to predict the time and cost performance. Also, Analysis of Variance (ANOVA) was used to carry out a simultaneous comparison of several population means; to determine whether or not variation in sets of data produce a different outcome. The method is used in this research to test a significant difference between the mean responses on time and cost performance of all the projects studied. It is a useful technique in modern statistical methods which enables the total variation in a set of data to be reduced to components associated with possible sources of variability whose relative impact needs to be accessed [20]. The variation between samples and within a sample are the possible sources of variability and for each source of variability, the sum of squares is computed using the degrees of freedom.

A total of 29 building projects were contracted and completed within the period 2005 to 2014 under the TETFund intervention programme in the three tertiary institutions selected for the study. Records were available on 23 of these projects representing $79 \%$ of the total number. Since the total population of professionals that participated in these projects could not be ascertained due to the mobility of labour and lack of accurate personnel records, especially in the contractor and consultant organizations, the research purposively targeted 75 respondents; 25 each from the 3 institutions. The purpose is to obtain an equal representation from each institution cutting across professionals who actively participated in the projects. For the interview, 5 of the 7 respondents with over 21years working experience were selected on the assumption that they are known as professionals on TETFund projects.

\section{Presentation and Discussion of Results}

A total of 62 out of 75 questionnaires were returned as valid, giving a response rate of $82.6 \%$. Table 1 shows the background of respondents comprising Quantity Surveyors (35.5\%), Architects (19.4\%) and 12.9\% Engineers, Builders and Estate Valuers each. This depicts a cumulative of $87.1 \%$, with a predominance of professionals commonly found on construction sites during the survey. However, a cumulative of $51.6 \%$ have experiences spanning over 10 years; an indication that the majority are reasonably experienced to contribute to the study. 
Table 1. Background of Respondents

\begin{tabular}{|c|c|c|c|c|c|c|c|c|}
\hline Profession & Frequency & $\begin{array}{c}\% \text { of } \\
\text { Response }\end{array}$ & Experience & Frequency & $\begin{array}{c}\% \text { of } \\
\text { Response }\end{array}$ & Organization & Frequency & $\begin{array}{c}\% \text { of } \\
\text { Response }\end{array}$ \\
\hline A rchitect & 12 & 19.4 & $\begin{array}{l}1-5 \\
\text { years }\end{array}$ & 8 & 12.9 & Contracting & 18 & 29.0 \\
\hline Builder & 8 & 12.9 & $\begin{array}{l}6-10 \\
\text { years }\end{array}$ & 20 & 32.3 & $\begin{array}{c}\text { Consultanc } \\
\mathrm{y}\end{array}$ & 22 & 35.5 \\
\hline Engineer & 12 & 19.4 & $\begin{array}{c}11-15 \\
\text { years }\end{array}$ & 10 & 16.1 & $\begin{array}{c}\text { Governmen } \\
\mathrm{t}\end{array}$ & 22 & 35.5 \\
\hline $\begin{array}{l}\text { Quantity } \\
\text { Surveyor }\end{array}$ & 22 & 35.5 & $\begin{array}{c}16-20 \\
\text { years }\end{array}$ & 8 & 12.9 & & & \\
\hline Others & 8 & 12.9 & $\begin{array}{c}\text { Over } \\
\text { 21years }\end{array}$ & 14 & 22.6 & Total & 62 & 100.0 \\
\hline \multirow[t]{2}{*}{ Total } & 62 & 100.0 & $\begin{array}{c}\text { Total } \\
\text { M issing }\end{array}$ & $\begin{array}{c}60 \\
2\end{array}$ & $\begin{array}{c}96.8 \\
3.2\end{array}$ & & & \\
\hline & & & Total & 62 & 100.0 & & & \\
\hline
\end{tabular}

SOURCE: Field Survey, 2015

\subsection{Factors That Promote Choice of Fixed Price Contract}

Among factors that influence the choice of the traditional procurement route presented in Table 2, firmness of cost was rated highest with $58.1 \%$ response rate as a "very important" factor. This is followed by early completion with $54.8 \%$; quality expectation with $45.2 \%$ and risk reduction with $32.3 \%$. Hence the requirement for the firmness of cost and adherence to the time schedule for early completion are important factors that influenced the choice of a fixed price contract.

Table 2. Factors that influence the choice of the procurement system

\begin{tabular}{|c|c|c|c|c|}
\hline Factors & Rating & Frequency & Percentage & $\begin{array}{l}\text { Cumulative } \\
\text { Percentage }\end{array}$ \\
\hline \multirow{4}{*}{ Quality expectation } & Not important & 8 & 12.9 & 12.9 \\
\hline & Important & 26 & 41.9 & 54.8 \\
\hline & V ery important & 28 & 45.2 & 100 \\
\hline & Total & 62 & 100 & \\
\hline \multirow{4}{*}{ Firmness of cost } & N ot important & 4 & 6.5 & 6.5 \\
\hline & Important & 22 & 35.5 & 51.6 \\
\hline & V ery important & 36 & 58.1 & 100 \\
\hline & Total & 62 & 100 & \\
\hline \multirow[t]{5}{*}{ Early completion } & N ot important & 4 & 6.5 & 6.5 \\
\hline & Important & 24 & 38.7 & 45.2 \\
\hline & V ery important & 34 & 54.8 & 100 \\
\hline & Total & 62 & 100 & \\
\hline & Not important & 6 & 9.7 & 9.7 \\
\hline \multirow[t]{3}{*}{ Risk reduction } & Important & 36 & 58.1 & 67.7 \\
\hline & Very important & 20 & 32.3 & 100 \\
\hline & Total & 62 & 100 & \\
\hline
\end{tabular}




\subsection{Time-Cost Performance}

The differences in time and cost data of the projects studied were collected from three different institutions. A total of 23 projects were involved. Figure 1 and Figure 2 are a graphical representation of the time and cost relationship of these projects.

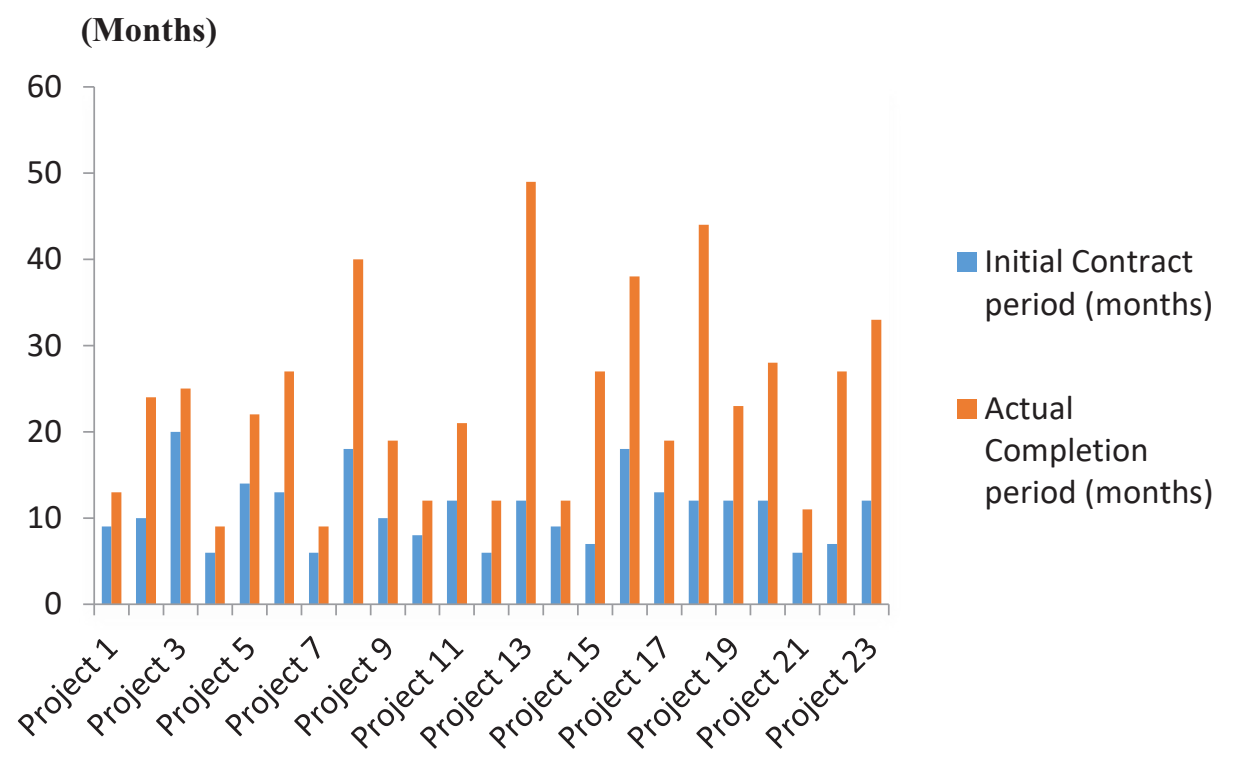

Fig.1. Initial and actual completion period (Naira)

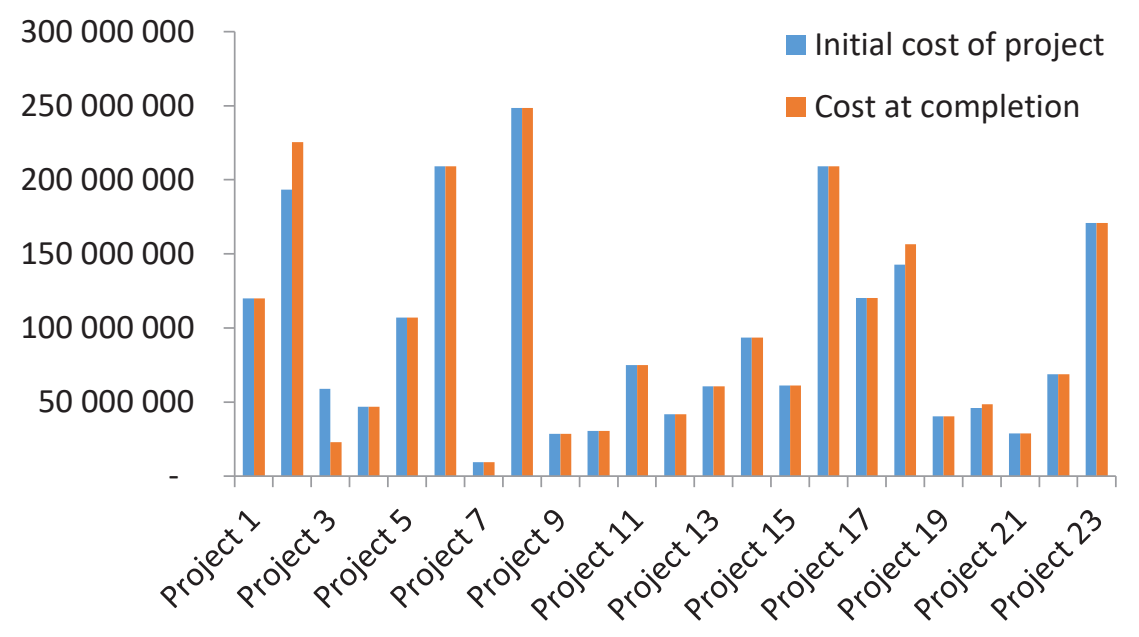

Fig. 2. Initial and actual cost of the project (Naira)

\subsection{Results and Discussions}

Results of the analysis are presented in Tables 3, 4 and 5.

Linear regression was used to assess the ability of initial and actual time to predict the actual cost. Preliminary analysis was conducted to ensure there is no violation of the normality, linearity, multi co-linearity and homoscedasticity. The initial and actual time was 
entered as independent variables while the final cost was entered as the dependent variable. The total variance explained by the model as a whole was $59.79 \%$, degree of freedom F (2.10) $=2.78, \mathrm{P}$-value $>0.05, \mathrm{R}=0.597$, $\mathrm{R}$-square $=0.225$.

From the model summary in Table 3, This is an overall measure of the strength of association and does not reflect the extent to which any particular independent variable is associated with the dependent variable. Finally, the variables were not statistically significant.

The implication of these to decision-makers, as shown in Table 5 is that when all other variables are held constant; there is an $\$ 5,192,491.09$ (currently equivalent to $\$ 14,423.59$ ) unit increases in the actual cost for every unit increase in months in actual time. This is however insignificant as shown on the $\mathbf{t}$ and Sig. columns. Interpreting these statistics with respect to the projects studied shows that the cost increase emanated from 5 out of 23 projects. This explains the reason for the insignificance as 18 of the projects which did not have a cost increase despite the time overrun.

Table 3. M odel Summary

\begin{tabular}{ccccc}
\hline Model & R & R Square & $\begin{array}{c}\text { Adjusted R } \\
\text { Square }\end{array}$ & Std. Error of the Estimate \\
\hline 1 & $.597^{\text {a }}$ & .357 & .228 & 70845434.285 \\
\hline \multicolumn{5}{r}{} \\
\hline \multicolumn{5}{r}{ Predictors: (Constant), A ctual Time, Initial Time }
\end{tabular}

Table 4. ANOVA

\begin{tabular}{cccccc}
\hline Model & Sum of Squares & Df & Mean Square & F & Sig. \\
\hline Regression & 27857091313126228.000 & 2 & 13928545656563110.000 & 2.775 & $.110^{\mathrm{b}}$ \\
Residual & 50190755589642976.000 & 10 & 5019075558964298.000 & & \\
Total & 78047846902769216.000 & 12 & & & \\
\hline
\end{tabular}

a. Dependent $V$ ariable: A ctual Cost

b. Predictors: (Constant), A ctual Time, Initial Time

Table 5. Coefficients of A ctual Cost

\begin{tabular}{cccccr}
\hline Model & Unstandardized & Coefficients & $\begin{array}{c}\text { Standardized } \\
\text { Coefficients } \\
\text { Beta }\end{array}$ & T & Sig. \\
\hline (Constant) & 32947133.123 & 65933111.008 & & .500 & .628 \\
Initial Time & -3464037.680 & 6464861.182 & -.171 & -.536 & .604 \\
$\begin{array}{c}\text { A ctual } \\
\text { Time }\end{array}$ & 5192491.092 & 2419787.654 & .686 & 2.146 & .057 \\
\hline
\end{tabular}

a. Dependent V ariable: Actual Cost 
The outcome of the interviews shows that although time and cost overruns were experienced, these were accommodated within the contingencies cost of the projects and also because of the firmness of the contract, material specifications and scope of work were changed. This further supports earlier studies of the significant relationship between time and cost. The participants further explained that where the scope of the work was not changed but due to delay in payments and honouring of architects certificates; these have led to increasing the running cost of the project. Other factors identified were inadequate design information which leads to discrepancies in the bill(s) of quantities, and also inadequate time provided for detailed design and other contract documents all of which contribute significantly to the delay and poor performance of the project.

\section{Conclusion}

In conclusion, this study was able to establish and build to the existing body of knowledge by identifying the key factors that promote the use of fixed-price/lump sum contract on TETFUND projects in Nigeria. The firmness of the cost is the major factor for adopting this type of contract. While out of the 23 projects studied, 5 suffered from cost-overrun and all the 23 suffered from time overrun. What this study indicates is that there is a trade-off in the quality of the project while trying to meet the cost target. This trade-off will eventually lead to the higher maintenance cost of the facility. Furthermore, the study found out that in the evaluation of time and cost performance of building projects executed through a fixedprice contract, the practice that allows time to overrun without adequate allowance in the cost element of buildings, and yet expecting to have a building as specified in the design, scope and quality is unrealistic.

Therefore, the study suggests that for effective use of the fixed-price contract, there is a need for team collaboration and detailed identification of the client's priority and objectives (cost, quality and time). On the alternative, the study recommends that public institutions can take advantage of the experience of project teams by adopting other alternative procurement methods that provide some level of flexibility and also gaining from the design and construction expertise of teams.

\section{References}

1. S.A. L upton, S. Cox, H. Clamp, Which Contract? Choosing the appropriate building contract: RIBA Publishing Enterprises, (2007)

2. F.L. B ennett, The management of construction: A project lifecycle approach: R outledge (2007)

3. P.E.D. Love, M. Skitmore, G. Earl, Selecting a suitable procurement method for a building project, Construction Management \& Economics 16(2):221-233 (1998)

4. J. M asterman, An introduction to building procurement systems: Routledge (2003)

5. A. Ghadamsi, N. Braimah, The influence of procurement methods on project performance: A conceptual framework (2012)

6. D. B oyd, E. Chinyio, Understanding the construction client: J ohn W iley \& Sons (2008)

7. S.T. K ometa, P.O. Olomolaiye, F.C. Harris, A review of client-generated risks to project consultants, International Journal of Project Management 14(5):273-279 (1996)

8. K.F. Potts, Construction cost management: Learning from case studies. Oxon: Taylor $\&$ Francis (2008)

9. O.A. Olatunji, A comparative analysis of tender sums and final costs of public construction and supply projects in Nigeria, Journal of Financial Management of Property and Construction 13(1):60-79 (2008) 
10. O.A. A dedokun, O.T. Ibironke, S.O. B abatunde, A ssessment of competitive tendering methods of procuring educational building projects in Nigeria. Journal of Facilities Management, 11(1):81-94 (2013)

11. A.A. Olanrewaju, P.J. A navhe, Perceived claim sources in the Nigerian construction industry, Built Environment Project and Asset Management 4(3):281-295 (2014)

12. E. U wandu, TETF und responsible for $60 \%$ infrastructure development in public tertiary institutions - B afa, (2017), https://www.vanguardngr.com>news

13. J. Agbakuru, TETFund releases $\$ 1 T r n$ to Varsities, Polytechnic in 5years, (2017), https://www.vanguardngr.com>news

14. JCT, Deciding on the appropriate JCT contract. Practice note. Published in A ugust 2006 by Sweet \& M axwell Limited (2006), retrieved from www.jctcontracts.com

15. J. Rodriguez, Lump Sum: What Is A Lump Sum? Lump Sum Construction Contract, (2013), http://www.about.com guide. A ccessed on M ay 7, 2013

16. K.K. Chitkara, Project management - planning, scheduling and controlling, New Delhi: Tata M cGraw Hill (2005)

17. Y.D. Izam, Construction Estimating and Procurement Issues: A monograph of the Department of Building, University of J os, Nigeria (2014)

18. S. M. Shwarka, N.A. A nigbogu, The impact of public procurement options on building projects performance in Nigeria, The Professional Builder 3(2):46 - 54 (2012)

19. R.K. Y in, Case study research design and methods $\left(3^{\text {rd }}\right.$ ed. $)$ Cal ifornia: Sage Publications (2003)

20. D.C. Howell, Statistical methods for psychology, Wadsworth Group: CA (2002) 


\section{Appendix - Research Questionnaire}

\section{SECTION I: GENERAL BACKGROUND OF RESPONDENT}

Kindly fill the information below (Tick).

$\begin{array}{llll}\text { 1. Type of your organization (a) Contractor (b)Consultancy } & \text { (c) Government }\end{array}$

2. What is your profession? (a) A rchitect $\quad$ (b) Builder $\quad$ (c) Engineer (d) Quantity Surveyor

(e) Others; kindly specify....

3. Y our years of working Experience
(a) $1-5$ years
$\begin{array}{lll}\text { (b) } 6-10 \text { years } & \text { (c) } 11-15 \text { years }\end{array}$
$\begin{array}{lll}\text { (d) } 16-20 \text { years } & \text { (e) A bove 21years }\end{array}$

4. In which of these institutions have you supervised or executed building projects (multiple answers are accepted)
(a) University
(b)Polytechnic/College of A gric
(c) College of Education
(d) Others; kindly specify....

5. From the list provided below, tick the type of project you were involved with in the box that follows: (multiple answers are accepted)
(a) Residential
(b) Lecture theatre
(c) M ultipurpose block
(c) Laboratory/workshop
(e) Others; kindly specify

\section{SECTION II: NATURE AND PERFORMANCE OF PROJECT EXECUTED}

6. Which of these procurement systems was used for the project? (multiple answers are accepted)
(a) Separated/traditional system
(b) M anagement oriented system
(c) Design and Build system
(d) Discretionary/Partnering system

K indly indicate your level of "agreement" or "disagreement" by ticking in the box that corresponds to each factor to answer questions (7) to (12)

7. Rate the following factors with respect to how they affect the choice of procurement system, type and form of contract

\begin{tabular}{|c|c|c|c|c|c|}
\hline Factors & $\begin{array}{r}\text { Very } \\
\text { significant }\end{array}$ & Significant & Uncertain & $\begin{array}{c}\text { Less } \\
\text { significant }\end{array}$ & $\begin{array}{c}\text { Not } \\
\text { significant }\end{array}$ \\
\hline $\begin{array}{l}\text { Quality } \\
\text { expectation }\end{array}$ & & & & & \\
\hline $\begin{array}{l}\text { Firmness } \\
\text { of Cost }\end{array}$ & & & & & \\
\hline $\begin{array}{l}\text { Early } \\
\text { completion }\end{array}$ & & & & & \\
\hline $\begin{array}{l}\text { Risk } \\
\text { reduction }\end{array}$ & & & & & \\
\hline
\end{tabular}

8. In the light of your past/present experience, how have the following elements of fixed price contract affect contract performance?

\begin{tabular}{|c|l|l|l|l|l|}
\hline$\downarrow \quad$ Rlements & $\begin{array}{c}\text { Very } \\
\text { significant }\end{array}$ & Significant & Uncertain & $\begin{array}{c}\text { Less } \\
\text { significant }\end{array}$ & $\begin{array}{c}\text { Not } \\
\text { significant }\end{array}$ \\
\hline Completeness of Design & & & & & \\
\hline Frequency of Change Orders & & & & & \\
\hline Extent of Cost V ariation & & & & & \\
\hline Extent of Delay & & & & & \\
\hline
\end{tabular}




\begin{tabular}{|l|l|l|l|l|l|}
\hline A dequacy of Tendering Time & & & & & \\
\hline Integrity of A ward Process & & & & & \\
\hline
\end{tabular}

\section{SECTION III: CHALLENGES IN PROJECT EXECUTION}

9. How critical were the following factors in your project execution?

\begin{tabular}{|l|l|l|l|l|l|}
\hline Factors Rating & $\begin{array}{l}\text { Very } \\
\text { critical }\end{array}$ & Critical & $\begin{array}{l}\text { Uncertai } \\
\text { n }\end{array}$ & $\begin{array}{l}\text { Less } \\
\text { critical }\end{array}$ & $\begin{array}{l}\text { Not } \\
\text { critical }\end{array}$ \\
\hline Design inadequacies & & & & & \\
\hline $\begin{array}{l}\text { Additional requirement of the } \\
\text { client }\end{array}$ & & & & & \\
\hline $\begin{array}{l}\text { Compliance with new } \\
\text { government legislation }\end{array}$ & & & & & \\
\hline $\begin{array}{l}\text { Discrepancy in contract } \\
\text { drawings or bill of quantities }\end{array}$ & & & & & \\
\hline $\begin{array}{l}\text { Non-availability of contract } \\
\text { specified materials/goods }\end{array}$ & & & & & \\
\hline $\begin{array}{l}\text { Substitution of materials, goods } \\
\text { and workmanship specified in } \\
\text { the contract }\end{array}$ & & & & & \\
\hline
\end{tabular}

\section{SECTION IV: PROBLEMS AND PROSPECTS OF FIXED PRICE CONTRACT}

10. Rate the significance of the following problems associated with fixed price contract in project delivery.

\begin{tabular}{|l|l|l|l|l|l|}
\hline \multicolumn{1}{|c|}{ Rating $\longrightarrow$} & $\begin{array}{c}\text { Very } \\
\text { significant }\end{array}$ & Significant & Uncertain & $\begin{array}{c}\text { Less } \\
\text { Significant }\end{array}$ & $\begin{array}{c}\text { Not } \\
\text { Significant }\end{array}$ \\
\hline $\begin{array}{l}\text { Changes are difficult to } \\
\text { assess/costly to } \\
\text { implement }\end{array}$ & & & & \\
\hline $\begin{array}{l}\text { Lower financial risk to } \\
\text { employer }\end{array}$ & & & & & \\
\hline $\begin{array}{l}\text { Need to complete design } \\
\text { before bidding }\end{array}$ & & & & \\
\hline $\begin{array}{l}\text { Contractors not adhering } \\
\text { to quantities/specification }\end{array}$ & & & & \\
\hline $\begin{array}{l}\text { Hard to build relationship } \\
\text { as each project is unique }\end{array}$ & & & & & \\
\hline $\begin{array}{l}\text { Bidding can be expensive } \\
\text { and lengthy }\end{array}$ & & & & & \\
\hline $\begin{array}{l}\text { Delays in honouring } \\
\text { Architect's certificate }\end{array}$ & & & & \\
\hline $\begin{array}{l}\text { Project/Environmental } \\
\text { related problems }\end{array}$ & & & & \\
\hline $\begin{array}{l}\text { Consultant related } \\
\text { problems }\end{array}$ & & & & \\
\hline
\end{tabular}


11. Rate the significance of the following prospects associated with fixed price contract in project delivery.

\begin{tabular}{|l|l|l|l|l|l|}
\hline$\downarrow$ Prospects & $\begin{array}{c}\text { Very } \\
\text { significant }\end{array}$ & Significant & Uncertain & $\begin{array}{c}\text { Less } \\
\text { Significant }\end{array}$ & $\begin{array}{c}\text { Not } \\
\text { Significant }\end{array}$ \\
\hline Lower financial risk to Employer & & & & & \\
\hline M inimum owner supervision & & & & & \\
\hline Higher incentive for Contractor & & & & & \\
\hline $\begin{array}{l}\text { Contractor selection is relatively } \\
\text { easy }\end{array}$ & & & & & \\
\hline
\end{tabular}

12. From a strategic point of view, rate the factors that would improve the fixed price contract system

\begin{tabular}{|l|l|l|l|l|l|}
\hline$\downarrow$ Factors & $\begin{array}{c}\text { Very } \\
\text { significant }\end{array}$ & Significant & Uncertain & $\begin{array}{c}\text { Less } \\
\text { Significant }\end{array}$ & $\begin{array}{c}\text { Not } \\
\text { Significant }\end{array}$ \\
\hline $\begin{array}{l}\text { A dequate design and } \\
\text { specifications }\end{array}$ & & & & & \\
\hline $\begin{array}{l}\text { Stable conditions (Government } \\
\text { policies) }\end{array}$ & & & & & \\
\hline $\begin{array}{l}\text { Effective competition when } \\
\text { bidding }\end{array}$ & & & & & \\
\hline $\begin{array}{l}\text { M inimum scope changes } \\
\text { (adequacy of brief) }\end{array}$ & & & & & \\
\hline $\begin{array}{l}\text { Sufficient time to bid and award } \\
\text { project }\end{array}$ & & & & & \\
\hline
\end{tabular}

13. Please proffer other factors that you feel can improve project delivery through fixed price contract system. 